КРИТЕРІЇ ТА ПОКАЗНИКИ ДІАГНОСТУВАННЯ СФОРМОВАНОСТІ ОРГАНІЗАЦІЙНОЇ КОМПЕТЕНТНОСТІ В МАЙБУТНІХ ФАХІВЦІВ ІЗ ФІЗИЧНОї КУЛЬТУРИ І СПОРТУ ЗБРОЙНИХ СИЛ УКРАЇНИ

\title{
CRITERIA AND INDICATORS OF DIAGNOSIS OF FORMATION OF ORGANIZATIONAL COMPETENCE IN FUTURE SPECIALISTS IN PHYSICAL CULTURE AND SPORTS OF THE ARMED FORCES OF UKRAINE
}

Стаття присвячена проблемі фрормування організаційної компетентності в майбутніх фохівиів з фрізичної культури і спорту Збройних сил України. Обгрунтовано зміст понять «критерій», «показник», «рівні сорормованості», викладено загальні вимоги до критеріїв. У даному дослідженні здійснено аналіз наукових праць щодо діагностування сорормованості організаційної компетентності у спеціалістів, зокрема фрахівців з фрізичноі культури і спорту Збройних сил України, інформацію узагальнено. Вибір відповідних критеріїв і показників здійснено з урахуванням специфріки їхніх військово-професійних та управлінських фуннцій, а також дослідницьких завдань, які поставлені в науковому дослідженні. Розглянуто особливості впливу організаційної компетентності на якість профресійної діяльності та ї̈ результативність. Зазначено специфрічні риси проведення діагностичного дослідження організаційноі компетентності в майбутніх фрахівців 3 фрізичної культури і спорту Збройних сил України. Враховуючи зміст і специфріку їхньоі військово-професійної та фрахової діяльності, виокремлено ціннісно-мотиваційний, когнітивний, діяльнісний, менеджерський, індивідуально-психічний (профресійно важливі якості) і суб'єктний критерії діагностування організаційної компетентності. Для кожного критерію підібрано відповідні показники - емпірично визначені якості досліджуваних для більш деталізованого оцінювання їхної організаційної компетентності. Обірунтовані критерії та показники дадуть змогу визначити сучасний стан сформованості організаційної компетентності майбутніх фрахівців з фрізичної культури і спорту Збройних сил України. Проведена наукова розвідка актуального стану рівнів сфрормованості організаційної компетентності у фахівців різного напряму. Охарактеризовано чотири рівні сорормованості організаційної компетентності в майбутніх фрахівців з фрізичної культури і спорту Збройних сил України - низький, задовільний, достатній і високий. Доведено, що виокремлені критерії та показники надають можливість якісно реалізовувати діагностичний етап дослідження і конкретизувати основні педагогічні умови фрормування в них організаційної компетентності.

Ключові слова: організаційна компетентність, критерії, показник, рівні, фрахівець з фрізичної культури і спорту, сорормованість, діагностування.

The article is devoted to the problem of formation of organizational competence in future specialists in physical culture and sports of the Armed Forces of Ukraine. The content of the concepts "criterion", "indicator", "levels of formation" is substantiated, the general requirements to the criteria are stated. In this study, an analysis of scientific works on diagnosing the formation of organizational competence of specialists, including specialists in physical culture and sports of the Armed Forces of Ukraine, the information is summarized. The selection of appropriate criteria and indicators is made taking into account the specifics of their militaryprofessional and managerial functions, as well as research tasks set in the research. The peculiarities of the influence of organizational competence on the quality of professional activity and on its effectiveness are considered. Specific features of the diagnostic study of organizational competence of future specialists in physical culture and sports in the Armed Forces of Ukraine (hereinafter - IFC) are indicated. Taking into account the content and specifics of their military-professional and professional activities, the value-motivational, cognitive, activity, managerial, individual-mental (professionally important qualities) and subjective criteria for diagnosing their organizational competence are distinguished. For each criterion, appropriate indicators are selected - empirically determined qualities of the subjects for a more detailed assessment of their organizational competence. Substantiated criteria and indicators will allow to determine the current state of formation of their organizational competence. Scientific research of the current state of the levels of formation of organizational competence of specialists in various fields has been carried out. Four levels of formation of organizational competence of future specialists in physical culture and sports of the Armed Forces of Ukraine are characterized low, satisfactory, sufficient and high. It is shown that the selected criteria and indicators provide an opportunity to qualitatively implement the diagnostic stage of the study and specify the basic pedagogical conditions for the formation of organizational competence.

Key words: organizational competence, criteria, indicator, levels, specialist in physical culture and sports, formation, diagnosis.
Постановка проблеми в загальному вигляді. Українському суспільству потрібні офріцери, які $\epsilon$ справжніми військовими професіоналами загалом та професіоналами вузького спрямування, зокрема, наприклад, офіцер у сфрері фрізичної підготовки та спорту, оскільки на нього покладається відповідне коло повноважень щодо фрізичної під- готовки військовослужбовців і водночас конкретне коло обов'язків як командира та начальника, менеджера і військовослужбовця, тобто організатора фрізичної підготовки і спорту у військовій частині. Якість їхньої організаторської діяльності визначається сорормованістю організаційної компетентності. Від його організаційної підготовле- 
ності, вміння приймати відповідальні рішення, організовувати не лише власну діяльність, а й службову діяльність підлеглих, координувати та управляти фрізичним вихованням усього військового підрозділу (частини). Отже, виникає необхідність обґрунтування критеріїв і показників діагностування організаційної компетентності майбутніх фрахівців з фрізичної культури і спорту Збройних сил України (далі - МФФК). Проблема її діагностування в контексті організації фрізичної підготовки військовослужбовців виникає в спеціально професійно зумовлених ситуаціях, спрямованих на покращення їх фрізичної підготовленості як суб'єктів екстремального виду діяльності. Обґрунтування критеріїв і показників оцінювання її сорормованості для покращення якості їх організаційної підготовленості як менеджерів фрізичної підготовки та спорту в 3С України.

Аналіз останніх досліджень і публікацій. Аналіз результатів наукових досліджень дав зрозуміти, що зазначеній проблемі присвячена чимала кількість напрацювань. Тож серед усіх варто відзначити таких авторів та їхні роботи: І.О. Бєліков приділяє увагу проблемі організаційної компетентності у військових фрахівців та її фрормуванню в педагогічній науці [1]; Д.О. Перепльотчиков підготовці майбутніх фрахівців з фрізичного виховання і спорту до організації діяльності ДЮСШ [12]; Д.В. Погребняк, В.В. Ягупов й Є.В. Малахов обґрунтували систему критеріїв оцінювання розвиненості фрахової компетентності у начальників фрізичної підготовки і спорту військових частин [2]; B.І. Свистун зі співавторами розглянув роль фрізичного виховання в професійній діяльності науковопедагогічного складу [3]; Н.Б. Вербин розробив конкретні критерії та показники діагностування профресійно-прикладної фрізичної підготовленості майбутніх магістрів військового управління [7]; Р.Г. Шостак дослідив діагностування сорормованості управлінської компетентності в майбутніх начальників фрізичної підготовки і спорту військової частини [13].

Виділення не вирішених раніше частин загальної проблеми. Педагогічне дослідження проводиться в межах дисертаційного дослідження на тему «Формування організаційної компетентності в майбутніх фрахівців з фрізичної культури і спорту Збройних сил України» в Національному університеті оборони України імені Івана Черняховського.

Мета статті полягає в обґрунтуванні системи критеріїв діагностування сфрормованості організаційної компетентності у фрахівців з фрізичної культури і спорту Збройних сил України (далі - 3С України) та визначенні їхніх показників.

Виклад основного матеріалу. В процесі військово-професійної діяльності реалізація функціональних обов'язків будь-якого військового фрахівця, зокрема фрахівця з фрізичної культури і спорту, залежить від різних чинників. Одним із головних $\epsilon$ сорормованість їхньої організаційної компетентності. Погоджуємося 3 думкою В.В. Ягупова та В.Ю. Киви, що однією з методологічних вимог до організації педагогічного експерименту $є$ виокремлення й обґрунтування критеріїв та показників діагностування його результатів, а також з'ясування рівнів вияву тих якостей, які фрормуються і розвиваються в респондентів під час проведення педагогічного експерименту [10, с. 252]. Згідно 3 цим успішність організаторської діяльності МФФК значною мірою залежить від їхньої організаційної компетентності. Тож цей напрям є орієнтиром для подальшої експериментальної роботи з МФФК, що спонукає нас до чіткого визначення критеріїв і показників, за якими можна діагностувати результати сорормованості організаційної компетентності.

Вважаємо, що критерії і показники діагностування сорормованості організаційної компетентності у МФФК мають бути пов'язані зі змістом їхньої організаторської діяльності та реалізацією управлінської функції як менеджерами фрізичної підготовки та спорту у військовій частині. Відповідно до обґрунтованих нами компонентів їхньої організаційної компетентності - ціннісно-мотиваційного, когнітивного, діяльнісного, менеджерського, індивідуально-психічного та суб'єктного, доцільно визначити відповідні критерії діагностування ії сорормованості на основі використання багаторівневого аналізу та 3 урахуванням провідних ідей і положень компетентнісного, діяльнісного, суб'єктного та контекстного підходів до військовопрофесійної підготовки в системі військової освіти.

Отже, необхідно діагностувати організаційну компетентність в МФФК на основі дотримання вимог компетентнісного підходу до її фрормування як фрахівців фрізичної підготовки та спорту (дотримуємося вимог діяльнісного та контекстного підходів до фрормування організаційної компетентності), які $\epsilon$ професіоналами екстремального виду діяльності в ЗС України (дотримуємося вимог суб'єктнодіяльнісного підходу до фрормування організаційної компетентності).

Насамперед необхідно визначити поняття «критерії» і «показник». Вважаємо, що наукове визначення критеріїв і показників діагностування сорормованості організаційної компетентності в МФФК з урахуванням специфіки їхньої організаторської діяльності у військовій частині $€$ важливим дослідницьким завданням як у теоретичному, так і в практичному аспектах. Слід зазначити, що до критеріїв необхідно сорормулювати чіткі вимоги, зокрема такі: «об'єктивність, тобто відображення ознак, притаманних предмету, який досліджується, незалежно від свідомості та волі суб'єкта дослідження; відображення суттєвих ознак предмета діагностування; стійкість і постійність досліджува- 
них ознак; зв'язок із цілями, завданнями, фрункціями та змістом конкретного дослідження; безпосередній зв'язок між метою і кінцевим результатом досліджуваного явища» [14, с. 117].

Поняття «критерій» як основна вимога до оцінювання управлінців почало вживатися досить недавно. Ще в 20-30 рр. ХХ ст. основними вимогами до управлінця були «ознаки» та «якості», «групи якостей», «умови» тощо [5, с. 144]. Критерій (в перекладі 3 грецької - засіб судження, переконання, мірило) - це «мірило для визначення, оцінювання предмета чи явища; ознака, взята за основу класифікацій»; «підстава для оцінювання чогось» [6, с. 241].

У тлумачному словнику української мови критерій розглядається як «засіб судження, підстава для оцінювання, визначення або класифікації чогось; мірило» [8, с. 588]. С.У. Гончаренко трактує критерії як «показники, що об'єднують в собі методи розрахунку, теоретичну модель розподілу і правила прийняття рішення про правдоподібність нульової або однієї 3 альтернативних гіпотез» [9, с. 181].

Отже, в загальному розумінні критерій - це важлива й визначальна ознака досліджуваного явища чи процесу, що характеризує основні якісні аспекти явища та, найголовніше, сутність, оскільки він у загальному вигляді $є$ більш стабільним і стійким, тобто наділений властивістю багаторазового використання. Н.Б. Вербин слушно вважає, що «вибір критерію оцінювання педагогічного явища одночасно має припускати вибір найбільш оптимальних (раціональних) показників, які повинні досить повно характеризувати рівень розвиненості профресійної витривалості» [7, с. 136].

Надумку науковців, критерій-це мірило, ознака, за допомогою якої визначається, наприклад, компетентність викладачів, що безпосередньо дає можливість з'ясувати ступінь її сорормованості та розвиненості за різними показниками на основних етапах педагогічного експерименту [10, с. 253].

Таким чином, критерій - це мірило, за допомогою якого можна визначити ступінь відповідності кількісної або якісної міри заданим вимогам (шкалі, рівням) згідно з методикою конкретного педагогічного дослідження. У дослідженні критерії дають змогу як визначати зміст та актуальний стан сорормованості організаційної компетентності на різних етапах педагогічного експерименту, так і з'ясувати динаміку їі сорормованості/розвиненості. 3 огляду на це можемо вважати, що обрані критерії мають бути об'єктивними, включати суттєві ознаки досліджуваного явища - організаційну компетентність МФФК, і відображати динаміку її сфрормованості в процесі педагогічного експерименту. Проведена наукова розвідка дала зрозуміти, що поняття «критерій» і «показник» тісно пов'язані між собою.

Організаційна компетентність МФФК є сукупністю організаційних цінностей і мотивацій, знань, умінь і навичок, професійно важливих якостей щодо збору та аналізу інфрормації, прийняття організаційних рішень, організації комунікації та взаємодії 3 військовослужбовцями насамперед в екстремальних умовах діяльності. Кінцевою метою організаційної діяльності $€$ ефективне вирішення різноманітних повсякденних, навчальних, навчально-бойових і бойових завдань військовим підрозділом (частиною) [1]. Сорормованість організаційної компетентності утворює основу організаційної культури МФФК, сприяє створенню позитивного психологічного клімату в військовій частині, що забезпечує високу та якісну продуктивність фрізичної підготовки військовослужбовців у військових підрозділах, підвищення позитивного іміджу 3С України в цілому [4].

Діагностичне дослідження сорормованості організаційної компетентності МФФК має бути спрямоване на з'ясування її дійсного стану. Водночас, як свідчить військовий досвід, реорганізація 3С України викликає, на жаль, в офріцерів втрату впевненості у майбутньому, у службовому професійному зростанні.

Для визначення стану сформованості організаційної компетентності МФФК доцільно проводити констатувальний експеримент, основним завданням якого $€$ виявлення сучасного стану їі сорормованості та перспектив проведення фрормувального експерименту. Більшість МФФК, здобуваючи професійну освіту, не можуть відповідати вищим рівням профресійної готовності, а це означає, що потрібна шкала, яка має досить дрібну градацію, щоб точно диференціювати стан сорормованості їхньої організаційної компетентності. Зважаючи на це, зупинимося на 6 критеріях і 4 рівнях сорормованості організаційної компетентності. 3 огляду на структуру їхньої професійної діяльності та вимоги діяльнісного підходу до розуміння цілей, змісту та структури будь-якої професійної діяльності основними компонентами організаційної компетентності МФФК вважаємо ціннісно-мотиваційний, когнітивний, діяльнісний, менеджерський, індивідуально-психічний, рефлексивно-оцінний, або суб'єктний [5, с. 687].

Отже, враховуючи завдання, цілі, зміст, специфріку, особливості та результати військово-профресійної і фрахової діяльності МФФК, сучасні методологічні вимоги до змісту їхньої організаційної компетентності, визначаємо критерії та показники діагностування її сорормованості.

Ціннісно-мотиваційний критерій вкрай необхідний, оскільки «...смисл цінностей в освіті полягає насамперед у тому, що вони фрормують систему значень, принципів, норм, канонів та ідеалів, які визначають важливість освіти в суспільстві, регулюють взаємодію суб'єктів в освітній сорері і фрормують ціннісний компонент у структурі навчальної діяльності тих, хто здобуває певну освіту, педагогічної діяльності викладачів. Це пов'язано з тим 
фрактом, що цінності, по-перше, фрормують найголовніше для кожної особи та фрахівця - їхнє ставлення до світу, речей, діяльності, інших людей і до самого себе; по-друге, визначають в освіті поведінку і суть діяльності ії суб'єктів, зокрема ставлення педагогів до педагогічної діяльності, їі смислу і результатів та ставлення учнів (студентів, слухачів) до здобуття освіти, навчальної діяльності та її смислу й основного результату. 3 огляду на це в педагогічних дослідженнях однією з основних цілей має бути з'ясування ціннісної сорери суб'єктів освіти: педагогів і тих, хто здобуває певну освіту учнів (студентів, слухачів)» [11, с. 52]. Ціннісномотиваційний критерій дає можливість з'ясувати: усвідомлення МФФК професійних і фрахових цінностей, настанов та їх сприйняття як орієнтирів майбутньої діяльності; позитивне ставлення до обраного фраху та майбутньої військово-професійної і фрахової діяльності; внутрішню вмотивованість до цієї діяльності та потребу в реалізації власного потенціалу у сорері фрізичної культури і спорту як суб'єкта військово-професійної та фрахової діяльності; потребу в набутті військово-професійних і фрахових знань, систематизації раніше набутих професійних (організаторських) умінь і навичок. Система цінностей і мотивації реалізує аксіологічну, стимуляційну та регулятивну фрункції в процесі орормування організаційної компетентності. Зміст цього критерію складають такі показники: фрахові потреби, мотиви та цінності.

Когнітивний критерій дає можливість 3'ясувати обізнаність і пізнання МФФК військовопрофресійної та фрахової дійсності, володіння певною сукупністю теоретичних і практичних знань, на яких ґрунтуються основи організаторської діяльності й практичне мислення як фахівця, та способи оволодіння знаннями. У своєму дослідженні виокремлюємо дві групи показників - діяльнісні та менеджерські, які складаються 3 військово-профресійних організаторських (знання, які необхідні кожному офіцеру для виконання військово-професійних завдань), фрахових (знання організації процесу фрізичної підготовки та вдосконалення військовослужбовців; знання теорії і методики фрізичного виховання, теорії та методики підготовки спортсменів; знання теорії та організації фрізичної підготовки військ; володіння поняттєвим апаратом фрізичної культури і спорту; знання провідних напрямів фрізкультурно-спортивної діяльності, основ фрізичної реабілітації і першої медичної допомоги) і педагогічних (знання принципів і закономірностей навчання, засобів, методів, фрорм організації фрізичної підготовки особового складу; здатність співвідносити педагогічні цілі з засобами і методами фрізичної підготовки та виховання особового складу; знання основних педагогічних підходів, методик і технологій щодо реалізації своїх посадових компетенцій як менеджера фрізичної підготовки та спорту у військах, вміння реалізовувати їх у своїй організаторській діяльності) знань.

Діяльнісний критерій дає можливість з'ясувати здатність МФФК використовувати військово-професійні і фахові знання під час вирішення ними організаційних завдань та успішно застосовувати набуті військово-професійні і фрахові (організаційні) знання в процесі реалізації посадових компетенцій як офіцера. Цей критерій дозволяє з'ясувати опанування МФФК військовопрофесійних і фрахових знань про сучасні технології управління й менеджменту в військах, готовність до самостійного планування й організації своєї діяльності як офріцера, здатність організовувати діяльність інших суб'єктів військового середовища, можливість успішного делегування своїх повноважень підлеглим.

Отже, показниками діяльнісного критерію є: праксеологічні вміння та навички успішно вирішувати практичні військово-професійні завдання, вміння оцінювати обстановку, приймати рішення і домагатися їх виконання; організаторські навички та вміння як офріцеращодо діяльності в екстремальних ситуаціях; вміння організувати діяльність особового складу та власну діяльність; вміння своєчасно й якісно виконувати накази та розпорядження старшого начальника, приймати рішення, чітко та якісно доводити їх до відповідних посадових осіб; навички та вміння вирішувати конфрліктні ситуації.

Менеджерський критерій дає можливість з'ясувати здатність МФФК організовувати свою діяльність у сорері фрізичної підготовки та спорту у військовій частині. Потреба в менеджменті у військовому середовищі зумовлена необхідністю мотивування, управління, організації, координації та контролю діяльності особового складу у сфері фрізичної підготовки та спорту. Саме планування (прогнозування), організація, координація, мотивування та контролювання процесів фрізичної підготовки і спорту у військовій частині вимагають сорормованості організаційних навичок і вмінь.

Показники менеджерського критерію такі: мотивування військовослужбовців військової частини до занять фрізичним вихованням та спортом; планування (прогнозування) заходів фрізичного виховання та спорту за участю особового складу військової частини; організація заходів фрізичного виховання та спорту за участю особового складу військової частини; координація заходів фрізичного виховання та спорту за участю особового складу військової частини; контролювання заходів фрізичного виховання та спорту за участю особового складу військової частини.

Індивідуально-психічний критерій - це поєднання професійно важливих індивідуально-психічних якостей, що зумовлюють результативність виконання МФФК організаторської діяльності у сорері фрізичної культури і спорту в військовій час- 
тині, роблять їх оптимально придатними до вимог фраху, сприяють реалізації власного потенціалу, забезпечують незалежність, гнучкість й оперативність у прийнятті та ухваленні менеджерських рішень в стандартних і нестандартних ситуаціях діяльності особового складу військової частини та дозволяють брати на себе відповідальність за результати.

Цей критерій містить такі показники: домінантність (лідерство), комунікативність, відповідальність, організованість, професійна витривалість.

Суб'єктний критерій - це здатність МФФК діяти з чітким усвідомленням своєї відповідальності за дії; досягнення фрахових цілей організаторської діяльності, автономності та самостійності як організатора фрізичної підготовки і спорту, тобто усвідомлення самого себе як фахівця з фрізичної культури і спорту та суб'єкта організаційно-управлінської діяльності в військовій частині, що демонструє їх суб'єктне ставлення до себе як до професійного суб'єкта-організаторафрізичноїпідготовкитаспорту.

Організаторська діяльність МФФК включає взаємодію з іншими суб'єктами військово-професійної діяльності та сприяє актуалізації суб'єктності в різ- них видах військово-професійної і фрахової діяльності загалом та організаційній, зокрема. Зміст цього критерію розкривається за допомогою таких показників: активності, автономності, об'єктивної самооцінки, відповідальності, рефлексії та саморефрлексії, тобто бути суб'єктом організаторської діяльності в військовій частині чи об'єктом профресійної суб'єктності.

Вищезазначені критерії та відповідні їм показники $€$ основою для оцінювання рівнів ссрормованості організаційної компетентності в майбутніх фрахівців з фрізичної культури і спорту зС України (табл. 1).

Наступним етапом дослідження є визначення рівнів сорормованості організаційної компетентності у МФФК. Аналіз наукових доробків вітчизняних і закордонних вчених демонструє, що переважна більшість виокремлює 4 рівні сорормованості організаційної компетентності фрахівця: низький, задовільний, середній і високий. Вищезазначене дало змогу визначити в межах цієї статті такі рівні сорормованості організаційної компетентності МФФК - низький, задовільний, достатній і високий.

Таблиця 1

Критерії та показники діагностування сформованості організаційної компетентності МФФК

\begin{tabular}{|c|c|c|c|}
\hline Критерій & Показник & Методика & $\begin{array}{l}\text { Числові вираження } \\
\text { (бали за показник) }\end{array}$ \\
\hline \multirow{2}{*}{$\begin{array}{c}\text { Ціннісно- } \\
\text { мотиваційний }\end{array}$} & Фахові цінності & \multirow{2}{*}{$\begin{array}{l}\text { Анкетування, } \\
\text { тестування }\end{array}$} & 100 \\
\hline & Фахові мотиви & & 100 \\
\hline \multirow{3}{*}{ Когнітивний } & Діяльнісні знання як офріцера & \multirow{3}{*}{$\begin{array}{l}\text { Анкетування, } \\
\text { тестування }\end{array}$} & 100 \\
\hline & $\begin{array}{l}\text { Менеджерські знання як менеджера в сорері фрізич- } \\
\text { ної підготовки та спорту в ЗС України }\end{array}$ & & 100 \\
\hline & Педагогічні знання як педагога-менеджера & & 100 \\
\hline \multirow{2}{*}{ Діяльнісний } & Праксеологічні знання як офріцера & \multirow{2}{*}{$\begin{array}{l}\text { Анкетування, } \\
\text { тестування, } \\
\text { опитування } \\
\end{array}$} & 100 \\
\hline & Організаційні навички та вміння як офріцера & & 100 \\
\hline \multirow{5}{*}{ Менеджерський } & $\begin{array}{l}\text { Мотивування військовослужбовців до участі } \\
\text { в заходах фрізичного виховання і спорту та } \\
\text { зайняття фрізичним вихованням і спортом }\end{array}$ & \multirow{5}{*}{$\begin{array}{l}\text { Анкетування, } \\
\text { тестування }\end{array}$} & 100 \\
\hline & $\begin{array}{l}\text { Планування (прогнозування) заходів фізичного } \\
\text { виховання та спорту особового складу військової } \\
\text { частини }\end{array}$ & & 100 \\
\hline & \begin{tabular}{|l|} 
Організація заходів фрізичної підготовки та спорту \\
з конкретними категоріями особового складу
\end{tabular} & & 100 \\
\hline & $\begin{array}{l}\text { Координація організаційних заходів з фрізичної під- } \\
\text { готовки та спорту військовослужбовців }\end{array}$ & & 100 \\
\hline & \begin{tabular}{|l|} 
Контролювання заходів фрізичного виховання та \\
спорту особового складу військової частини \\
\end{tabular} & & 100 \\
\hline \multirow{5}{*}{$\begin{array}{l}\text { Індивідуально- } \\
\text { психічний (про- } \\
\text { фесійно важливі } \\
\text { якості) }\end{array}$} & Домінантність (лідерство) & \multirow{5}{*}{$\begin{array}{c}\text { Анкетування, } \\
\text { тестування, } \\
\text { спостереження, } \\
\text { психологічна } \\
\text { діагностика }\end{array}$} & 100 \\
\hline & Комунікативність & & 100 \\
\hline & Відповідальність & & 100 \\
\hline & Організованість & & 100 \\
\hline & Профресійна витривалість & & 100 \\
\hline \multirow{5}{*}{ Суб'єктний } & Самооцінка як організатора & \multirow{5}{*}{$\begin{array}{l}\text { Анкетування, } \\
\text { тестування }\end{array}$} & 100 \\
\hline & Реорлексивність & & 100 \\
\hline & Автономність & & 100 \\
\hline & Відповідальність & & 100 \\
\hline & Професійна суб'єктність & & 100 \\
\hline
\end{tabular}


Характеристика рівнів сорормованості організаційної компетентності у МФФК

\begin{tabular}{|c|c|}
\hline Рівні & Вияви \\
\hline 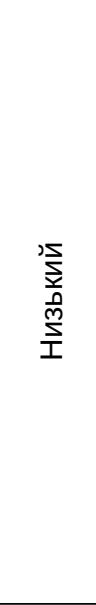 & 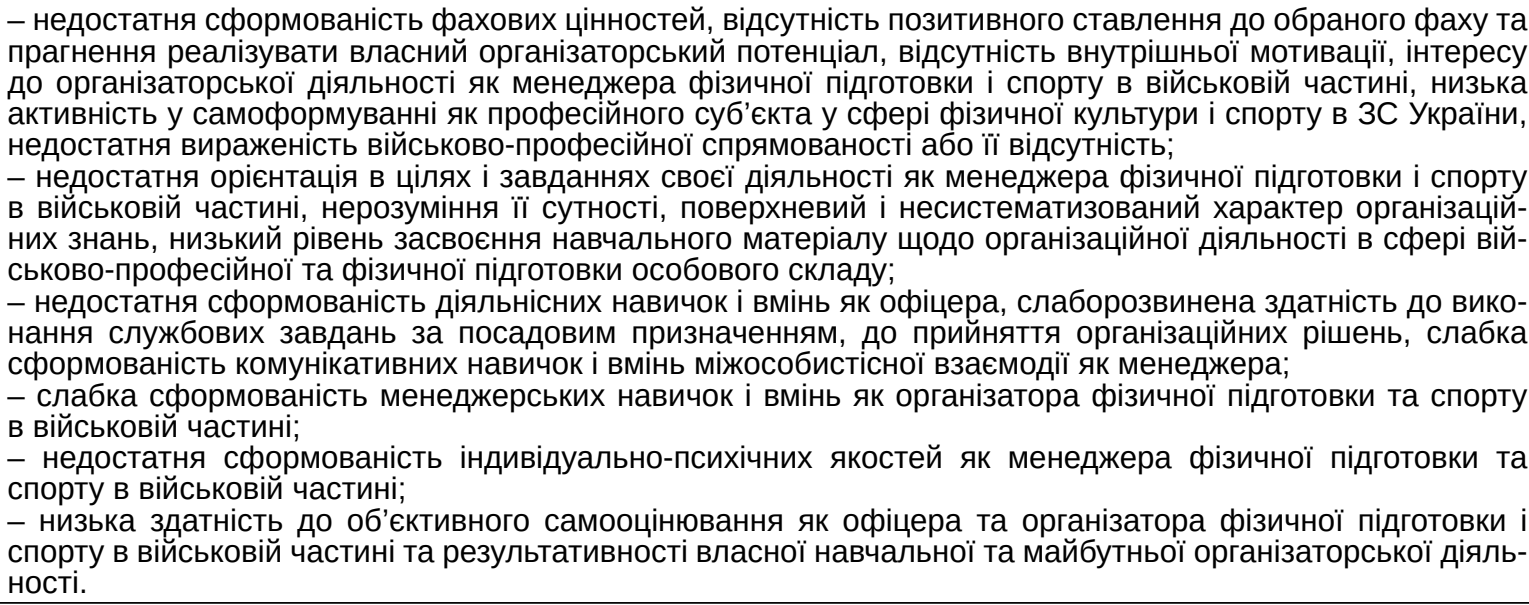 \\
\hline 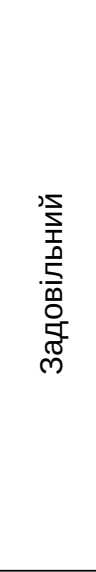 & 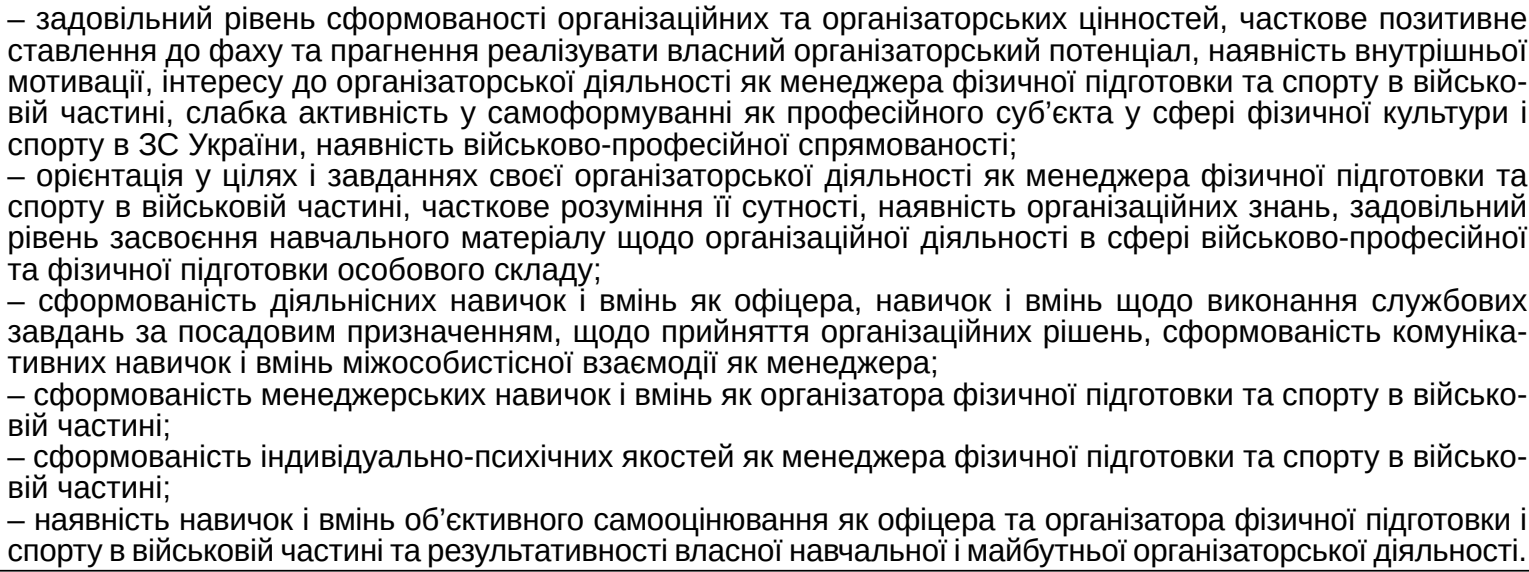 \\
\hline 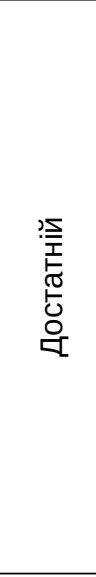 & 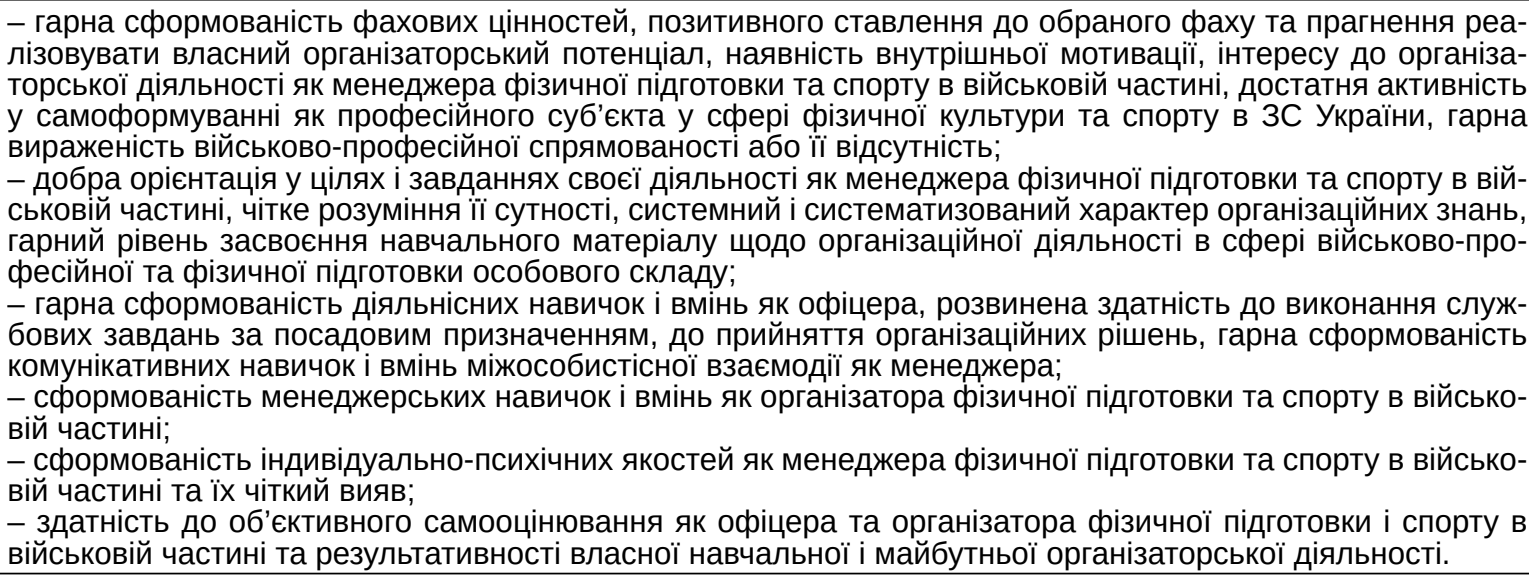 \\
\hline 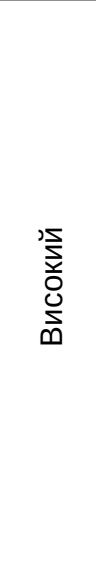 & $\begin{array}{l}\text { - чітка та стійка сорормованість фрахових цінностей, стійке позитивне ставлення до обраного фраху та } \\
\text { прагнення реалізувати власний організаторський потенціал, сформованість внутрішньої мотивації, інтер- } \\
\text { есу до організаторської діяльності як менеджера фрізичної підготовки та спорту в військовій частині, стійка } \\
\text { активність у самоформуванні як професійного суб'єкта у сфрері фрізичної культури та спорту в ЗС України, } \\
\text { яскрава вираженість військово-професійної спрямованості; } \\
\text { - чітка та стійка орієнтація у цілях і завданнях своєї діяльності як менеджера фрізичної підготовки та } \\
\text { спорту в військовій частині, творче розуміння її сутності, системний і контекстний характер організацій- } \\
\text { них знань, системний рівень засвоєння навчального матеріалу щодо організаційної діяльності в сфрері } \\
\text { військово-професійної та фрізичної підготовки особового складу; } \\
\text { - стійка сформованість діяльнісних навичокі вмінь як офіцера, творча здатність до виконання службових } \\
\text { завдань за посадовим призначенням, до прийняття організаційних рішень, сфрормованість комунікатив- } \\
\text { них навичок і вмінь міжособистісної взаємодії як менеджера; } \\
\text { - стійка сфрормованість менеджерських навичок і вмінь як організатора фрізичної підготовки та спорту } \\
\text { в військовій частині; } \\
\text { - стійка сфоромованість індивідуально-психічних якостей як менеджера фрізичної підготовки та спорту } \\
\text { в військовій частині; } \\
\text { - здатність до об'єктивного самооцінювання як офіцера й організатора фрізичної підготовки та спорту } \\
\text { в військовій частині і результативності власної навчальної та майбутньої організаторської діяльності. }\end{array}$ \\
\hline
\end{tabular}


У нашому дослідженні рівень - це ступінь сорормованості організаційної компетентності МФФК. Під рівнем їі сорормованості будемо розуміти стан досягнутих МФФК результатів в фрормуванні організаційної компетентності. Рівні їі сорормованості дають змогу трансформувати якісні показники у кількісні та дозволяють досить об'єктивно оцінювати ступінь сорормованості досліджуваного психолого-педагогічного явища за кожним компонентом із наступним узагальненням середньостатистичних величин для визначення сфрормованості конкретного компонента організаційної компетентності. Відповідно, доцільно виокремити рівні та основні вияви її сфоормованості - низький, задовільний, достатній і високий (табл. 2).

Низький рівень співвідноситься 3 недостатнім рівнем сорормованості основних складників організаційної компетентності МФФК, а їх організаційна діяльність за посадовим призначенням буде характеризуватися домінуванням репродуктивних організаторських дій, що виконуються виключно за встановленим шаблоном за стандартних ситуацій, і нездатністю до організаційної діяльності в нетипових і нестандартних ситуаціях.

МФФК з низьким рівнем сорормованості організаційної компетентності характеризуються неглибокими та поверховими знаннями про організаційну діяльність як організатора фрізичної підготовки та спорту в військовій частині; недостатнім засвоєнням теоретичних і практичних основ організаторської діяльності в сорері фрізичної підготовки та спорту в військовій частині та їх шаблонним застосуванням у процесі фрахової діяльності; майже байдужим ставленням до самовдосконалення у сорері фрізичної підготовки і спорту.

Задовільний рівень демонструє опосередковану обізнаність МФФК у сорері організації фрізичної підготовки та спорту в військовій частині і наявність зацікавленості в теоретичних основах її забезпечення, шаблонне прийняття рішень в екстремальних умовах у військовій сорері; на задовільному рівні відзначається їх самостійність щодо вибору доцільних організаційних дій, які потребують значного контролю керівного складу тощо; частково вміють обирати адекватний організаційний стиль, оптимальну стратегію та лінію поведінки відповідно до ситуації організаційної діяльності в шаблонних ситуаціях.

МФФК з задовільним рівнем сфрормованості організаційної компетентності мають несистемні та несистематизовані знання про засоби, методи і прийоми організаційної діяльності в професійнота фрахово-орієнтованому середовищі; посередні знання морально-етичних норм і правил професійного спілкування; фррагментарні знання щодо організаційної діяльності.

Середній рівень характеризується в цілому доволі сорормованими складниками організаційної компетентності МФФК, що потребує їх часткового покращення. Вони визначаються самостійністюпри виборі доцільних дій в організаторській діяльності, що потребують незначного за обсягом корегування під керівництвом наставників, мають досить широкий діапазон дій і стабільність їх демонстрації.

МФФК з середнім рівнем сорормованості організаційної компетентності мають стійкі, систематизовані знання про засоби, методи та прийоми організаційної діяльності у військово-професійному та фаховому середовищі; системні знання моральноетичних норм і правил профресійної взаємодії.

Високий рівень визначає в цілому високу сорормованість компонентів організаційної компетентності у МФФК, що не потребує їх суттєвого вдосконалення. На цьому рівні спостерігається їх цілковита обізнаність у виборі необхідних дій, широкий діапазон та стійкість вияву. МФФК з високим рівнем сорормованості є взірцем для інших в організаційній діяльності.

На високому рівні на прояви їхньої організаційної компетентності суттєвий вплив здійснює рівень стресостійкості. Це потрібно враховувати в процесі планування дослідження. Оптимізація стресостійкості професійної діяльності досягається насамперед формуванням у кожного 3 МФФК певних психічних якостей та фрункціональних можливостей, мотивації; підвищенням загальної й спеціальної тренованості, спрямованих на розвиток професійних, психічних і фрізичних функціональних можливостей; розвитком здатності до оптимальної мобілізації особистих можливостей та самоконтролю організму [15]. Прогнозування їхньої стресостійкості має значне наукове і практичне значення. Своєчасний прогноз стресостійкості, виявлення можливих відхилень у нормальному функціональному стані в окремих МФФК і своєчасна реалізація корекційних заходів допоможуть їм зберегти здоров'я, оптимізувати функціональний стан і підвищити ефективність профресійної діяльності у стресогенних умовах.

Основними проявами творчого рівня $€$ креативність і нешаблонність МФФК в організаційній діяльності, творче ставлення до організаційної діяльності за посадовим призначенням.

Висновки. Обґрунтування критеріїв і показників діагностування організаційної компетентності МФФК на констатувальному та фрормувальному етапах педагогічного експерименту $\epsilon$ актуальною науково-педагогічною проблемою, над вирішенням якої працюють вітчизняні й закордонні науковці. Аналіз наукових джерел уможливив з'ясування змісту основних понять педагогічного дослідження - «критерію», «показника» і «рівня сорормованості». Виокремлені критерії та показники для проведення комплексного діагностичного вивчення сорормованості організаційної компетентності МФФК охоплюють всі аспекти її прояву - 
ціннісно-мотиваційний, когнітивний, діяльнісний, менеджерський, індивідуально-психічний (професійно важливі якості) і суб'єктний. Доцільно враховувати їх при плануванні діагностичного дослідження, щоб отримати повне уявлення про рівень iï сорормованості та в подальшому спланувати заходи з їі цілеспрямованого формування, розвитку та вдосконалення.

Крім того, визначено та охарактеризовано 4 рівні сорормованості організаційної компетентності у майбутніх фрахівців з фрізичної культури і спорту ЗС України - низький, задовільний, достатній, високий, та надано їхні якісні вияви.

Перспективи подальших наукових досліджень полягають у визначенні методів, методик і засобів діагностування кожного показника сфрормованості організаційної компетентності у майбутніх фрахівців з фрізичної культури і спорту Збройних сил України.

\section{БІБЛІОГРАФІЧНИЙ СПИСОК:}

1. Бєліков І.О. Проблема організаційної компетентності військових фрахівців та їі фрормування у педагогічній науці. Science and Education a New Dimension. Pedagogy and Psychology. 2021. № 9. P. 17-23.

2. Погребняк Д.В., Ягупов В.В., Малахов Є.В. Система критеріїв оцінювання розвиненості фрахової компетентності начальників фрізичної підготовки і спорту військових частин Збройних сил України у системі післядипломної освіти. Science and Education a New Dimension. Pedagogy and Psychology. 2019. Sept. VII (82). Issue: 202, S. 45-51.

3. Griban, G., etc. The role of physical education in the professional activity of teaching staff. International Journal of Applied Exercise Physiology : Asian Exercise and Sport Science Association. 2020. Том 9. Вип. 5. P. 56-65.

4. Yahupov V., Bielikov I. Organizational competence of specialists in physical culture and sports of the armed forces of Ukraine: concept, content and structure. Role of science and education for sustainable development : Monograph 44 / Edited by Magdalena Wierzbik-Strońska and Iryna Ostopolets. Katowice : Publishing House of University of Technology, 2021. P. 682-690. http://www. wydawnictwo.wst.pl/uploads/files/f8b2328a3dbfcf8d510 300259fb8a101.pdf (дата звернення: 21.04.2021).

5. Бойко О.В. Формування готовності до управлінської діяльності у майбутніх магістрів військовосоціального управління : дис. ... канд. пед. наук : 13.00 .04 ; Ін-т педагогіки і психології профр. освіти АПН України. Київ, 2005. 244 с.

6. Шемчук В.А. Розвиток управлінського мислення у майбутніх магістрів військового управління в оперативно-тактичній ланці управління: критерії та показники. Нові технології навчання : наук.-метод. збірник. 2010. Вип. 66, ч. 2. С. 238-250.

7. Вербин Н.Б. Розвиток профеесійної витривалості майбутніх магістрів військового управління у процесі оперативно-тактичної підготовки : дис. ... канд. пед. наук : 13.00.04; Національний університет оборони України імені Івана Черняховського. Київ, 2019. 299 c.

8. Великий тлумачний словник сучасної української мови / уклад. і голов. ред. В.Т. Бусел. Ірпінь : ВТФ «Перун», 2009. 1736 с.

9. Гончаренко С.У. Український педагогічний словник. Київ : Либідь, 1997. 374 с.

10.Ягупов В.В., Кива В.Ю. Критерії та показники діагностування розвиненості інорормаційно-комунікаційної компетентності викладачів системи військової освіти. Інфрормаційні технології і засоби навчання. 2019. Том 71. № 3. С. 248-266.

11. Ягупов В.В. Аксіологічний вимір європейського освітнього простору та методологічні проблеми українських дослідників у педагогіці. Ціннісно-орієнтований підхід в освіті і виклики євроінтеграції : матер. міжнар. наук.-метод. конф., м. Суми, 29-30 травня 2020 р. / ред. колегія: В.М. Завгородня, А.М. Куліш та ін. Суми : Сумський державний університет, 2020. C. 51-53. https://drive.google.com/file/d/1ri7rvY i7d-gk9xPHYi5BWZlqrq-IdmX/view (дата звернення: 21.04.2021).

12. Перепльотчиков Д.О. Підготовка майбутніх фрахівців фрізичного виховання і спорту до організації діяльності ДЮСШ : автореф. дис. ... канд. пед. наук : 13.00.04. Запоріжжя, 2011. 20 с.

13.Шостак Р.Г. Діагностування сформованості управлінської компетентності майбутніх начальників фрізичної підготовки і спорту військової частини. Science and Education a New Dimension. Pedagogy and Psychology. 2021. № 9. P. 54-61.

14.Ягупов В.В., Фурс О.Й. Особливості діагностування психічної саморегуляції в майбутніх фахівців екстремальних видів діяльності. Організаційна психологія. Економічна психологія. 2018. № 1 (12). С. 116-123. [Електронний ресурс]. URL: http://orgpsyjournal.in.ua/userfiles/issues/i12/n12/14. pdf (дата звернення: 21.04.2021).

15. Свистун B.І. Стресостійкість військовослужбовців як необхідний чинник їхньої успішної військово-професійної діяльності в екстремальних умовах. Сучасні тенденції та перспективи розвитку фрізичної підготовки та спорту Збройних сил України, правоохоронних органів, рятувальних та інших спеціальних служб на шляху євроатлантичної інтеграції України : матеріали Міжнародної науковопрактичної конференції, м. Київ, 29-30 листопада 2017 р. ; Національний університет оборони України імені Івана Черняховського ; за заг. ред. В.І. Свистун, О.В. Петрачкової. Київ : НУОУ, 2017. С. 136-139. 